\title{
Principles of criminal law in the field of ensuring environmental safety
}

\author{
O.V. Knyazeva ${ }^{1}, K . A$. Sych $^{1}, O . K$. Khotkina $^{1 *}$ \\ ${ }^{1}$ Academy of the Federal penitentiary service of Russian Federation, 1 Sennaya str., Ryazan, 390000, \\ Russia
}

\begin{abstract}
Enormous scale of issues of protecting the natural environment becomes more and more obvious as well as issues of development of human civilization. Current criminal legislation (Art. 2 of the Criminal Code of Russian Federation) points to the protection of environment by means of law. This is the subject of Chapter 26 of the Criminal Code of Russian Federation "Environmental Crimes", where this group of crimes include water pollution (Art. 250 of the Criminal Code of Russian Federation), air pollution (Art. 251 of the Criminal Code of Russian Federation), marine pollution (Art. 252 of the Criminal Code of Russian Federation) ), damage to the land (Art. 254 of the Criminal Code of Russian Federation), destruction or damage of forest plantations (Art. 262 of the Criminal Code of Russian Federation). These types of crimes are especially relevant at present, after a number of emergency situations associated with river pollution in a number of regions, as well as cases with forest fires. In this regard, attention is drawn to the legislative list of principles of criminal law. In particular, the principle of justice (Article 6 of the Criminal Code of Russian Federation), which affects the interests of perpetrators of a crime. However, it should be recognized that the very category of "justice" presupposes not only consideration of interests of guilty person, but also interests of victim of a crime. Justice, as a principle of criminal law, should include, among other aspects, the restoration of victim's right violated by the crime and compensation for the harm caused to the victim.
\end{abstract}

\section{Introduction}

The issue of ensuring environmental safety was the object of research mainly by specialists in the field of environmental law. This issue was not raised and was not put for scientific discussion in the criminal law literature.

The very definition of the concept of environmental safety needs significant clarification, since Article 1 of the Federal Law "On Environmental Protection" dated 10.01. 2002 No. 7 defines ecological safety as environmental protection. However, in Part 1 of Art. 72 of the Constitution of Russian Federation it is stipulated that ensuring environmental safety and rational use of natural resources are independent areas of activity

*Corresponding author: a.copytowa@yandex.ru 
along with environmental protection. Provision of environmental safety by means of criminal law, in our opinion, can be reduced to a narrower concept associated with prevention and elimination of consequences of negative impact on the environment as a result of illegal and guilty human activities, since this is associated with the criminal liability. The purpose of the study is to determine principles of ensuring environmental safety by means of criminal law.

To achieve this goal, it is necessary to complete following tasks:

- to assess current Russian legislation in the field of environmental safety;

- to study criminal legislation of foreign countries in the field of regulation of ensuring environmental safety;

- to analyze statistical data (2016-2019) on the number of persons convicted of crimes provided for by Chapter 26 of the Criminal Code of Russian Federation (Diagram 1);

- to identify the main signs of corpus delicti related to pollution of environmental objects, and the peculiarities of their regulation in the Criminal Code of Russian Federation;

- to develop and substantiate proposals for improving the regulation of objective and subjective signs of pollution of waters, the atmosphere, the marine environment and damage to the earth, sanctions for their commission in the Criminal Code of Russian Federation and judicial practice.

\section{Research literature review and research methods}

Issues related to ensuring environmental safety and environmental protection have been the subject of research by many forensic scientists and criminologists. Thus, the issue of the concept and qualification of environmental crimes was considered by I.V. Popov; criminological characteristics of environmental crimes were studied by E.N. Zhevlakov, I.V. Popov (Moscow, 2015) [3]; the qualification of environmental crimes was the subject of research by N.A. Lopashenko (Moscow, 2009) [2] and A.M. Pleshakova (Moscow, 1994) [4]. We support the proposal of I.V. Popov, to add to the articles of Chapter 26 of the Criminal Code of Russian Federation a monetary criterion, in case of harm to the natural environment in an amount exceeding the limit established in the Law (Moscow, 2012) [1]. As we know, neither the administrative-legal, nor the civil-legal, nor the disciplinary responsibility in the environmental sphere can fully ensure the preventive and compensatory functions of law. Therefore, in the scientific literature, an opinion is expressed that criminal law does not play an independent role in environmental legal relations. So, E.N. Zhevlakov writes: "Criminal law protection is a part of the mechanism of legal protection of natural environment and plays only an auxiliary role (preventive, punitive, educational), (Moscow, 2012). The possibilities of criminal law in the protection of nature were considered by A.B. Babaev (Moscow, 2009) [8], he believes they are objectively limited, since it is not able to eliminate the causes of socially dangerous impact on nature. The features of its method (punitive-educational) limit the scope of this branch of law. O. Dubovik (Moscow, 1998) [5] also considered and proposed his own preventive measures in the field of environmental safety.

In the process of carrying out this research, various and private scientific methods of cognition were used. In the course of the research, historical and legal methods were used as well as formal-logical (dogmatic), comparative legal, statistical.

\section{Results}

The study shows that the principle of justice, enshrined in Art. 6 of the Criminal Code of Russian Federation covers only the interests of a perpetrator of a crime. Our proposals boil 
down to the fact that the legislative content of this principle would include the interests of a victim in the form of restoring the violated subjective right of the victim or compensation for harm caused by the crime to the victim.

The analysis of scientific works according to the scientist G. Krieger (Moscow, 1967) [7] shows that the appointment of a punishment to a guilty person should be made dependent on the results of compensation for harm to the victim.

The principle of humanism (Article 7 of the Criminal Code) should be supplemented with the aspect of ensuring the environmental safety of a person.

We trace the analysis of the issues of criminal liability for criminal pollution of the main objects of environment, taking into account the latest changes in the criminal legislation in this area and trends in its application in judicial practice. As a result, theoretical conclusions about the concept of environmental crimes and their system were formulated, the concept of unification of signs of corpus delicti (Articles 250-252, 254 of the Criminal Code of Russian Federation), strengthening of criminal liability and its corresponding differentiation for environmental pollution was put forward and substantiated, proposals for changing of some norms of the Criminal Code of Russian Federation and improvement of judicial practice were made.

\section{Discussion}

The main vector of discussion on the issue of environmental crimes comes down to the issues of interpretation of the doctrinal norms of the Criminal Code of Russian Federation, as well as the issue of blanket dispositions when qualifying the crimes in question (I.V. Popov, N.A. Lopashenko, A.M. Pleshakov).

However, the issue of environmental crimes was not considered from the standpoint of principles of criminal law, which are the basis of the current Criminal Code of Russian Federation. According to E.G. Kletneva (Kazan, 2005) [6], the considered acts in the form of pollution of environmental objects can be committed both intentionally and through negligence, therefore it would be advisable to increase the term of imprisonment from five to six years if they resulted in the death of a person. And for the pollution of environmental objects, resulting in the death of two or more persons by negligence, it is proposed to provide for an increase in the term of imprisonment.

Analysis of materials of the practice of imposing punishment, considered for environmental crimes, allowed us to come to the conclusion that courts do not always adequately assess the nature of public danger of crimes related to environmental pollution. Although most of the sanctions of the norms (8 out of 12) provide for a punishment in the form of imprisonment, it was not imposed at all.

It is characteristic that the main criterion for individualization of punishment for these crimes, that is recognized by courts is the identity of a perpetrator, not the degree of social danger of a crime. As one of the criteria for individualization of punishment, we propose to take into account the nature of the harm caused and the amount of environmental, property damage. 


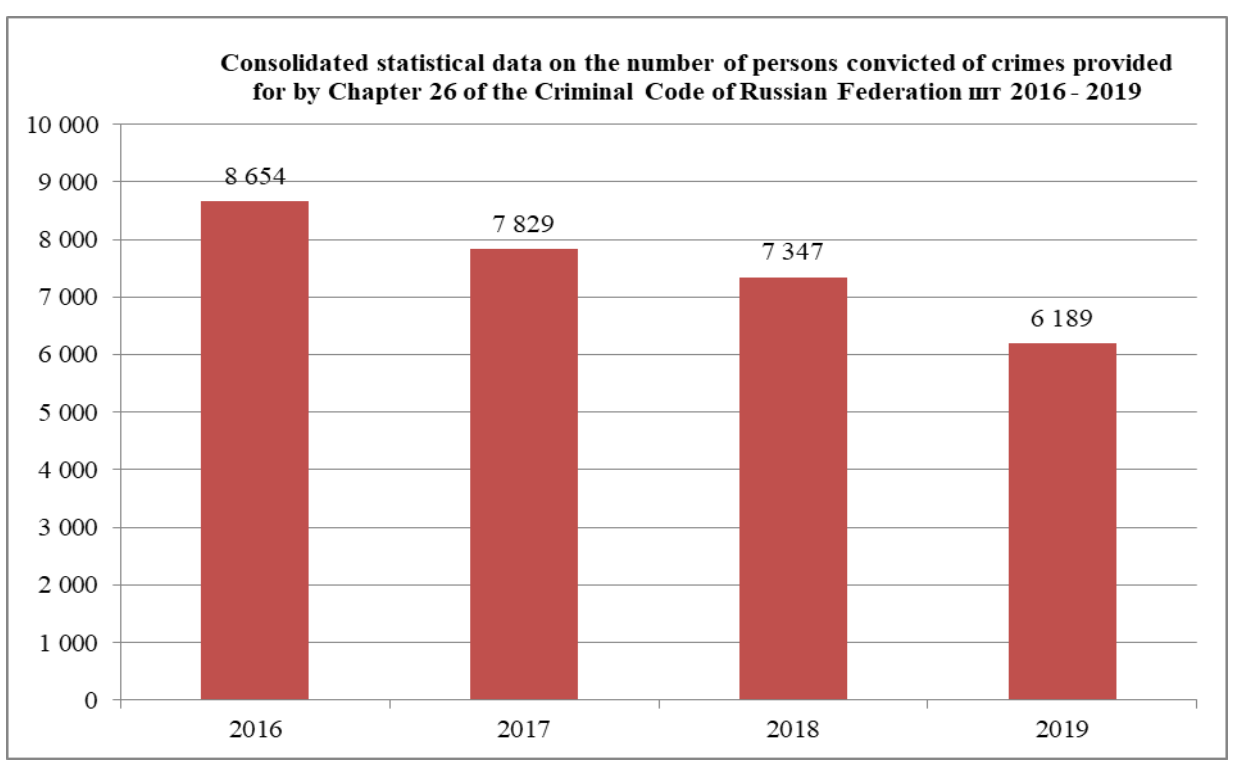

Fig. 1. Consolidated statistical data on the number of persons convicted of crimes provided for by Chapter 26 of the Criminal Code of Russian Federation шт 2016 - 2019.

It should be noted that the Decree of the President of Russian Federation of December 31, 2015 No. 683 "On the Strategy of National Security of Russian Federation" emphasizes that environmental issues are exacerbated due to the presence of a significant number of environmentally hazardous industries, lack of capacity for cleaning atmospheric emissions, industrial and urban wastewater, as well as insufficient efficiency of state control over the environment and a low level of environmental education and environmental culture of the population.

Therefore, environmental offenses have become almost the norm in various sectors of economic activity; it is associated with pollution of the biosphere, waters, land, destruction of biological resources of rivers and seas, predatory destruction of wildlife, forests, etc.

According to many experts, environmental crime in Russia and other countries is characterized by a high level of latency (97-99\%), although these crimes are always on the surface.

Measures to protect the environment, its individual objects from pollution are provided for in more than ten universal and regional Conventions, other international acts, including the Paris Agreement to fight global climate change of April 22, 2016, which entered into force on November 42016.

Regarding the principles of criminal responsibility for environmental crimes we are considering the Criminal Code of Russian Federation provides for a number of principles that are relevant to environmental protection.

First of all, the criminality of an act, its punishability and other criminal-legal consequences can be determined only in the Criminal Code of Russian Federation. This means that no other laws, including those on environmental protection, can provide for criminal liability other than the Criminal Code of Russian Federation.

The legislation also provides for the tasks of the Criminal Code of Russian Federation including environmental ones.

So, the tasks of the Criminal Code of Russian Federation are: protection of human and civil rights and freedoms (including environmental), property (including natural resources), public order and public safety (including environmental law and order), the environment, the constitutional order of Russian Federation against criminal encroachments, ensuring the 
peace and security of mankind (for example, by establishing criminal liability for ecocide), as well as preventing crimes (including environmental).

To ensure the prevention and suppression of environmental crimes, the principles of fairness of prosecution and application of punishment are of no small importance, meaning the need to establish a person's guilt in socially dangerous actions (inaction) and the onset of socially dangerous consequences. Objective imputation, that is, criminal liability for innocent harm, is not allowed. The punishment must be fair: it must correspond to the nature and degree of social danger of a crime, the circumstances of its commission and the personality of a perpetrator.

No one can be held criminally liable twice for the same crime. The basis for criminal liability is commission of an act containing all the signs of a crime provided for by the Criminal Code of Russian Federation.

Criminal legislation must ensure human security.

\section{Conclusion}

In Russia, despite the presence of colossal natural resources, environmental disasters were mostly natural until relatively recently. However, more environmental disasters are of a technogenic nature and, as a result, cause more harm every year with development of scientific and technological revolution,.

The evolution of science and technology in the field of personal life has led to a significant increase in the enterprises of gas, oil, chemical complex, and as a result, to an increase in harm to the environment.

Crime in the field of ecology includes a clear tendency towards development, especially in the last ten years, and, what is even more scary, it is beginning to acquire qualitative new features - professionalism and organization of its forms, as well as a selfish tendency.

Despite the fact that there are many discussions about what prevails in human behavior a social or biological principle, we assume that the basis of behavior of any person is, not biological, but social principles.

Summing up, we can say that, being the result of progress, criminality in the field of ecology is transformed into a phenomenon that has comparative independence, certain features and inherent only laws. And just as society affects crime and the environment, so environmental crime can influence the social relationships that gave rise to it.

As we said above, crimes in the field of ensuring environmental safety can be divided into several groups:

- Crimes that infringe on the environmental safety of the environment as a whole: (Art. 246, 247. 248 of the Criminal Code of Russian Federation);

- Crimes infringing on the environmental safety of natural complexes: (Art. 252, 253, 262);

- Crimes that infringe on the environmental safety of certain natural objects: (Art. 249, 250, 251, 255, 256, 257, 258 and 259 of the Criminal Code of Russian Federation).

It can be noted that the conditions and reasons for committing environmental crimes are related to each other - the cause gives rise only in the presence of special conditions.

It is very important to consolidate the organizational production of environmental social supervision, to significantly help the state law enforcement environmental authorities in the field of fighting environmental crimes.

The preventive ability of technical measures cannot be underestimated in the field of fighting environmental crimes. It begins with equipping law enforcement officers with the necessary special equipment. It is worth paying attention to the introduction of new achievements of science and technology in the detection, prevention and suppression of crime in the field of ecology, supervision of the welfare of the environment. 
The authors express their deep gratitude to the leadership of the Academy of the Federal Penitentiary Service of Russian Federation for the help and support provided in the course of this study.

\section{References}

1. Zhevlakov E.N. Environmental crimes: criminal law and criminological aspect: monograph. Moscow: University of Russian Academy of Education. 2002 .-- 159 p.

2. Lopashenko N.A. Environmental crimes: criminal legal analysis: monograph. M .: Publishing house "Yurlitinform. 2009 .-- 135 p.

3. Popov I.V. Crimes against the natural environment: theoretical foundations and practice of applying the norms of chapter 26 of the Criminal Code of Russian Federation: monograph. Moscow: Yurlitinform Publishing House. 2015 - 175 p.

4. Pleshakov A.M. Environmental crimes. Concept and qualifications: monograph. M .: Publishing house of the Academy of the Ministry of Internal Affairs of Russian Federation. 1994 .-- 184 p.

5. Dubovik O. L. Environmental Crimes: Commentary on Chapter 26 of the Criminal Code of Russian Federation. M., 1998 .-- 311 p.

6. Kletneva, E.G. Environmental crime at the turn of the XX-XXI centuries / Kazan: KYUI Ministry of Internal Affairs of Russian Federation, 2005. - 28 p.

7. Krieger G. Once again about mixed wine // Soviet justice, 1967 - N 3 - P. 50-54.

8. Babaev A.M. Fighting violations of the rules of hazardous waste handling: criminal law aspects // "Black holes" in Russian legislation. 2006. No. 3. - P. 210.

9. N. Zotkina, A. Kopytova, M. Zenkina, O. Zhigunova, MATEC Web of Conferences, 106, 08058 (2017) DOI: 10.1051/matecconf/201710608058

10. A.V. Kopytova, N.S. Zotkina, I.G. Reshetnikova, MATEC Web of Conferences 239, 04012 (2018) DOI: 10.1051/matecconf/201823904012

11. Lez'Er, V.A., Semeryanova, N.A., Kopytova, A.V., MATEC Web of Conferences, 239, 04027 (2018) DOI: 10.1051/matecconf/201823904027 